\title{
Late Pleistocene Paleoclimatology of the Central Equatorial Pacific: A Quantitative Record of Eolian and Carbonate Deposition
}

\author{
John M. Chuey, ${ }^{*}$ David K. Rea, ${ }^{*}, 1$ and Nicklas G. Pisias $\dagger$ \\ Received January 26, 1987
}

\begin{abstract}
Detailed records of $\delta^{18} \mathrm{O}, \delta^{13} \mathrm{C}$, percentage and mass accumulation rate of $\mathrm{CaCO}_{3}$, and eolian percentage, mass accumulation rate, and grainsize generated for core RC11-210 from the equatorial Pacific reveal the timing of paleoclimatic events over the past 950,000 yr. The $\mathrm{CaCO}_{3}$ percentage record shows the standard Pacific correlation of high $\mathrm{CaCO}_{3}$ content with glacial periods, but displays a marked change of character about $490,000 \mathrm{yr}$ ago with older stages showing much less variability. The carbonate mass flux record, however, does not show such a noticeable change. Sedimentation rates vary from about 0.5 to $3.0 \mathrm{~cm} / 1000 \mathrm{yr}$ and, during the past $490,000 \mathrm{yr}$, sections with enhanced sedimentation rates correspond to periods of high $\mathrm{CaCO}_{3}$ percentage. Eolian mass accumulation rates, an indication of the aridity of the source region, are usually higher during glacial times. Eolian grainsize, an indication of the intensity of atmospheric circulation, generally fluctuates at a higher frequency than the 100,000 -yr glacial cycle. The mid-Brunhes climatic event centered at 300,000 yr ago appears as a 50,000-yr interval of low intensity and reduced variability of atmospheric circulation. Furthermore, the nature of this entire record changes then, with the younger portion indicating less variation in wind intensity than the older part of the record. The late Matuyama increase in amplitude of paleoclimatic signals begins $875,000 \mathrm{yr}$ ago in the eolian record, $25,000 \mathrm{yr}$ before the $\delta^{18} \mathrm{O}$ and $\mathrm{CaCO}_{3}$ percentage amplitude increases about $850,000 \mathrm{yr}$ ago. 1987 University of Washington.
\end{abstract}

\section{INTRODUCTION}

Marine sediments contain a variety of records which may be used to help determine past climatic fluctuations. Pleistocene sediments have been of particular interest because of the dramatic changes in climate caused by the glacial/interglacial transitions. The equatorial Pacific has been the locus of many studies because of its accumulation of biogenic sediments.

The ratio of ${ }^{18} \mathrm{O}$ to ${ }^{16} \mathrm{O}$ in the carbonate tests of marine organisms has been used as a paleoclimatic indicator since the 1950's (Emiliani, 1955). Studies have shown that although the temperature of formation does affect the $\delta^{18} \mathrm{O}$ values of foraminifera tests,

* Department of Atmospheric and Oceanic Science, University of Michigan, Ann Arbor, Michigan 48109, and $\dagger$ College of Oceanography, Oregon State University, Corvallis, Oregon 97331

1 To whom correspondence should be addressed at Department of Geological Sciences, University of Michigan, Ann Arbor, MI 48109. the primary cause of the Pleistocene $\delta^{18} \mathrm{O}$ fluctuations is the changing oxygen isotope composition of the oceans due to ice-sheet growth and decay (Shackleton, 1967). Modern glacier ice has a $\delta^{18} \mathrm{O}$ of about -30 per mil, and the buildup of isotopically light ice caps causes an oceanic enrichment of $\delta^{18} \mathrm{O}$, with each 10 -m drop in sea level causing an oceanic $\delta^{18} \mathrm{O}$ increase of about 0.1 per mil (Shackleton, 1977a). The mixing time of the oceans is about $1000 \mathrm{yr}$, so $\delta^{18} \mathrm{O}$ fluctuations in samples from marine sediment cores from different locations are nearly simultaneous on a geological time scale (Shackleton and Opdyke, 1976). The $\delta^{18} \mathrm{O}$ record is therefore very useful for both stratigraphic and paleoclimatic purposes.

Ratios of ${ }^{13} \mathrm{C}$ to ${ }^{12} \mathrm{C}$ in carbonate tests have been recognized more recently for their usefulness as paleo-environmental indicators. It has been observed that $\delta^{13} \mathrm{C}$ values of benthic foraminifera tests generally fluctuate in correspondence with gla- 
cial/interglacial ages, with glacial times displaying lighter $\delta^{13} \mathrm{C}$ values by an average of 0.4 per mil (Shackleton and Pisias, 1985). These fluctuations in the ocean $\delta^{13} \mathrm{C}$ may be partially the result of the Pleistocene destruction and regrowth of organic biomass on the continents which have average $\delta^{13} \mathrm{C}$ values of -25 per mil (Shackleton, 1977b). A more important factor which may influence the oceanic $\delta^{13} \mathrm{C}$ record is the cyclic submersion and exposure of the continental shelves during Pleistocene sea-level fluctuations. During interglacial high sea levels, isotopically light marine organic carbon is deposited on the shelves; during glacial low sea levels, these sediments are subjected to subaerial erosion and the isotopically light carbon is returned to the sea (Berger et al., 1981; Broecker and Peng, 1982; Arthur et al., 1985).

Pleistocene calcium carbonate records of the equatorial Pacific have been used as paleoceanographic indicators since the work of Arrhenius (1952). Pacific sediments commonly show large-scale fluctuations in carbonate percentage, with a general pattern of high $\mathrm{CaCO}_{3}$ percentages corresponding to glacial times, and lower $\mathrm{CaCO}_{3}$ percentages corresponding to interglacial times. Arrhenius attributed these cycles to fluctuating productivity levels, with the oceans being more productive during glacial times due to increased turbulence. Adelseck and Anderson (1978) suggested that in areas where sediments are deposited above the lysocline, $\mathrm{CaCO}_{3}$ percentage fluctuations may indeed be primarily due to productivity changes, but, in general, Pacific $\mathrm{CaCO}_{3}$ percentage appears to be controlled by the corrosiveness of deep water to carbonate, and is therefore an indicator of bottom-water chemistry (Hays et al., 1969; Thompson and Saito, 1974).

Isolation and analysis of the eolian portion of marine sediments also yields paleoclimatic information. Studies have suggested that the mineral portion of deep-sea sediments far from terrestrial sources is dominated by wind-blown material (Windom, 1975; Leinen and Heath, 1981; Rea et al., 1985). The mass flux of this eolian material is an indication of the aridity of the source region, because humid climates promote vegetation which reduces the availability of dust for wind transport (Prospero and Nees, 1977; Prospero et al., 1981), and also because precipitation scavenges eolian dust, decreasing the flux of wind-blown material downwind (Windom, 1975; Parkin and Padgham, 1975). Approximately $2000 \mathrm{~km}$ from the eolian source region, grains reach a size distribution in equilibrium with the transporting winds. Beyond that point the eolian grainsize record should be a reflection of changes in the intensity of atmospheric circulation (Janecek and Rea, 1985). Several studies of eolian flux and eolian grainsize have been performed on Pacific sediments, and these have shown that eolian mass flux may either increase or decrease during glacial times depending on the local to regional source area aridity patterns, while the grainsize record generally fluctuates at a higher frequency than the 100,000 -yr glacial pattern (Janecek and Rea, 1985; Rea et al., 1986).

Each of these data sets records a diffcrent aspect of climatic variation. The temporal relationships among these various atmospheric, oceanic, and continental surface proxy indicators could be determined if the records were each determined in separate cores with very accurate stratigraphy, or if all of these data sets were generated from the same set of samples. This study utilizes the second strategy and compares data determined from samples of a single core.

\section{SEDIMENTS AND ANALYSES}

Core RC11-210 was retrieved from $1^{\circ} 49^{\prime} \mathrm{N}, 140^{\circ} 03^{\prime} \mathrm{W}$ in the central Pacific from a water depth of $4420 \mathrm{~m}$ (Fig. 1). This site is far from land and thus away from sites of hemipelagic deposition or significant bottom transport of terrigenous sedi- 


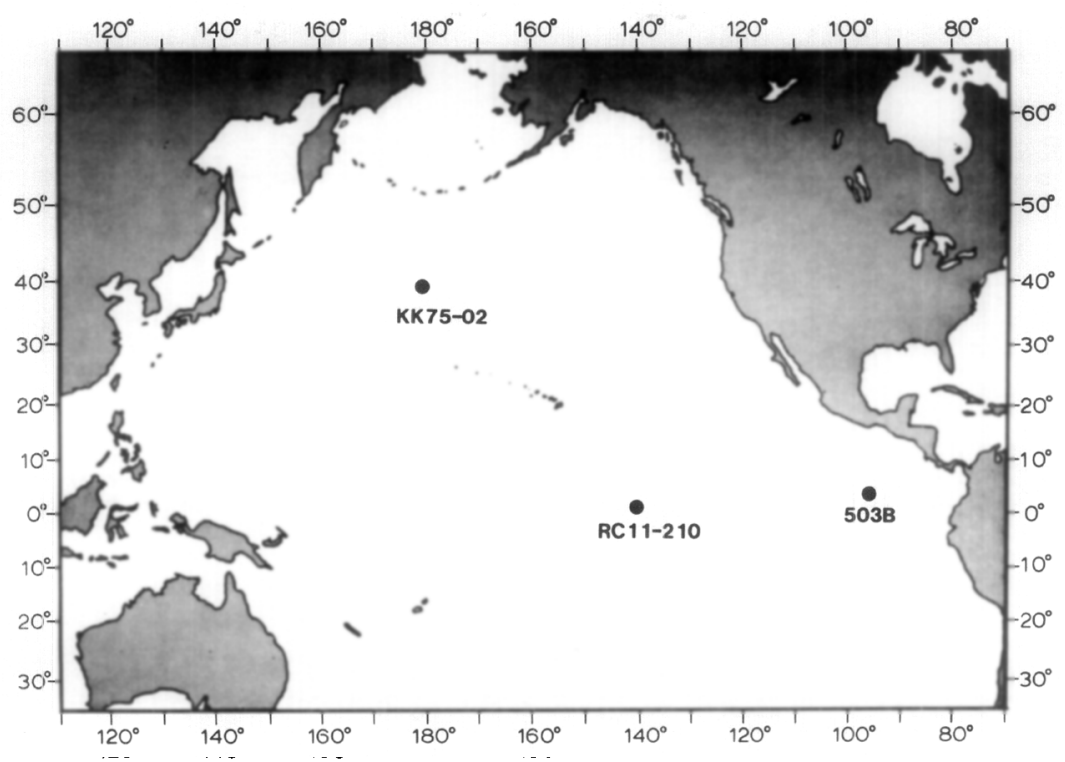

Fig. 1. Map of the Pacific Ocean showing locations of cores discussed in text.

ments, so the eolian signal is not confused by any of these processes. Core RC11-210 has a complete Brunhes record and a moderate average linear sedimentation rate of $1.5 \mathrm{~cm} / 1000 \mathrm{yr}$. This allows close temporal sample spacing, and, therefore, reasonably detailed records of the various paleoclimatic indicators.

For this study 175 samples were taken at $8-\mathrm{cm}$ intervals, giving an average temporal sample interval of about $5000 \mathrm{yr}$. Samples were freeze-dried, mechanically disaggregated, homogenized, and split into quarters. One quarter of each sample was analyzed for $\mathrm{CaCO}_{3}$ percentage using a carbonate bomb, with a resulting precision of $\pm 1 \%$. The second quarter was disaggregated, wet-sieved at $63 \mu \mathrm{m}$, and picked for samples of Globoratalia tumida, which were analyzed for $\delta^{18} \mathrm{O}$ and $\delta^{13} \mathrm{C} . G . t u$ mida, a deep-dwelling planktic foraminifera, was used because it was the only species consistently abundant enough for analysis throughout the core. This species has previously been analyzed for isotopic composition by Adelseck and Anderson (1978) and by Rea et al. (1986) with acceptable results. The analyses of $\delta^{18} \mathrm{O}$ and $\delta^{13} \mathrm{C}$ were performed on the mass spectrometer in the Stable Isotope Laboratory at the University of Michigan under the direction of $\mathrm{K}$. C. Lohmann. The precision of the resulting data is $\pm 0.08 \%$ for the $\delta^{18} \mathrm{O}$ data, and $\pm 0.04 \%$ for the $\delta^{13} \mathrm{C}$ values.

The third quarter of each sample was subjected to a series of chemical extractions to isolate the eolian component. A $25 \%$ acetic acid solution was used to remove calcium carbonate; a buffered sodium citrate and sodium dithionite solution was used to remove oxides, hydroxides, and zeolites; and warm sodium carbonate baths were used to remove opal. A more detailed description of this procedure is given by Rea and Janecek (1981). The eolian material thus extracted was weighed, and the weight percentage of this component was calculated. The resulting precision of this procedure is approximately $\pm 4 \%$. Grainsize distributions were then determined for the eolian component using a 16-channel Coulter Counter Model TA II particle size analyzer. The data are reported as median grainsize ( $\phi_{50}$ of Folk, 1974) and have a precision of $\pm 0.03 \phi$. The data from all of these analyses are presented in Table 1.

In this paper we present the basic data 


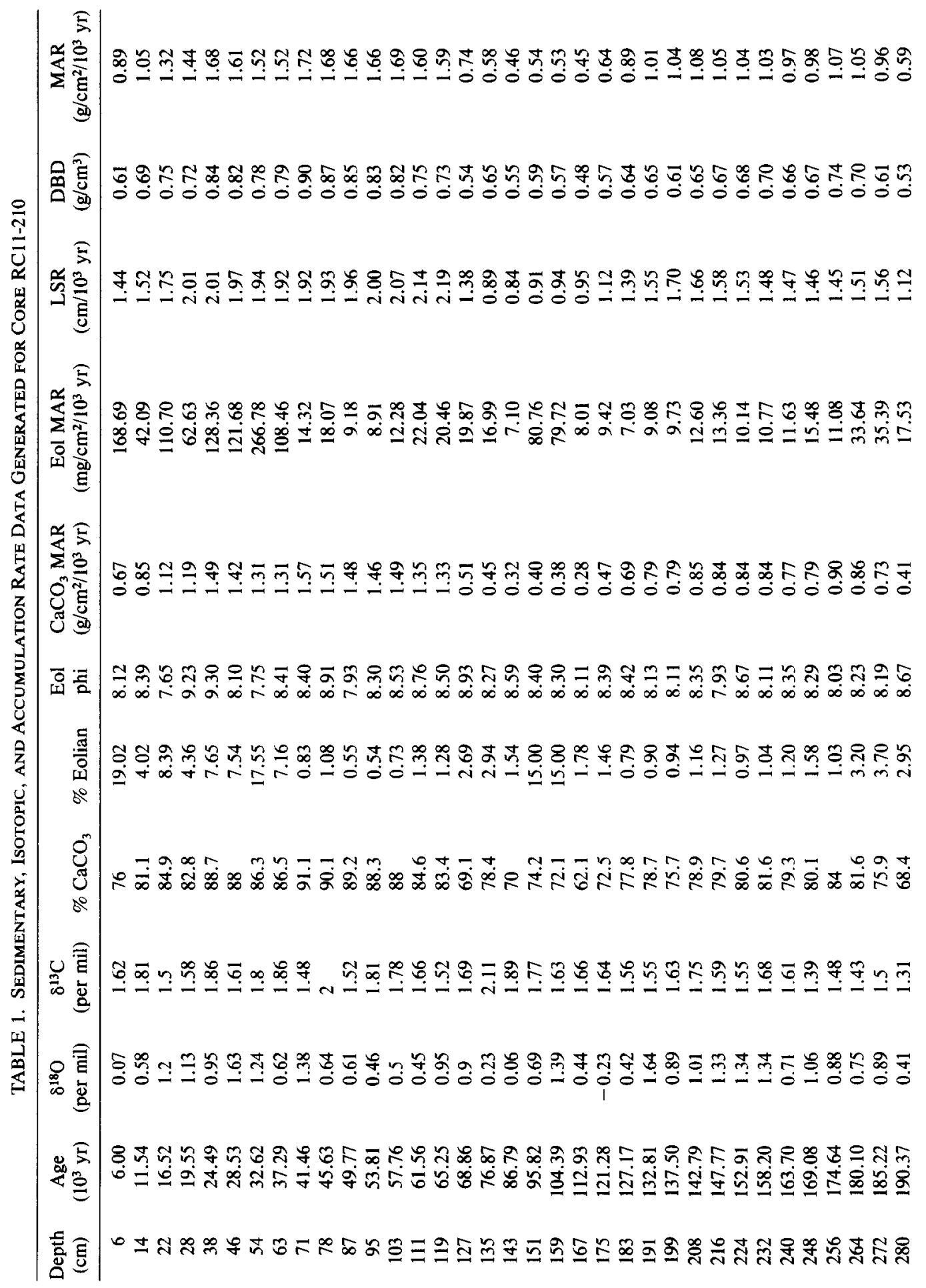




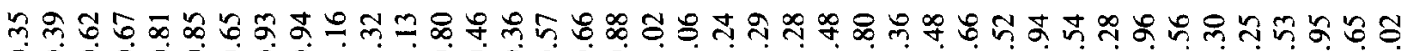

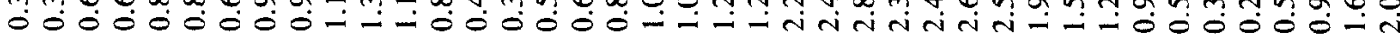

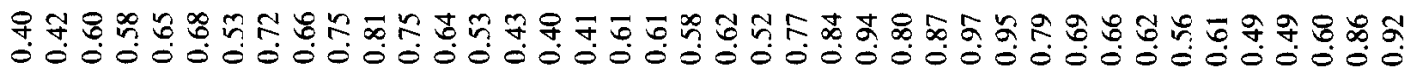

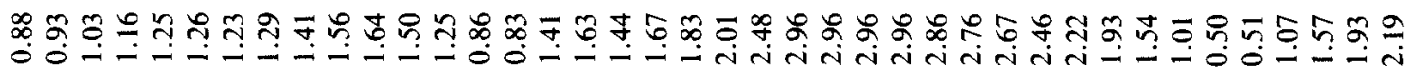

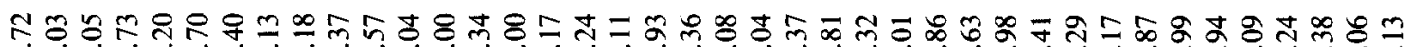

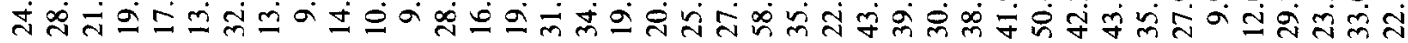

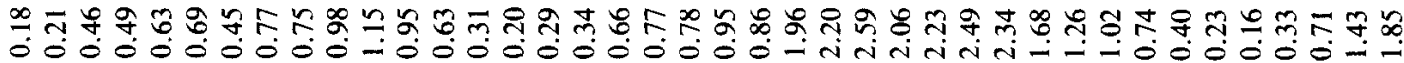

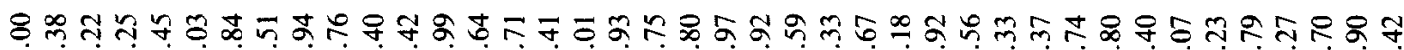

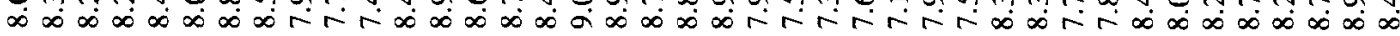

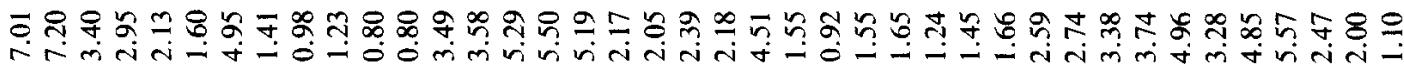

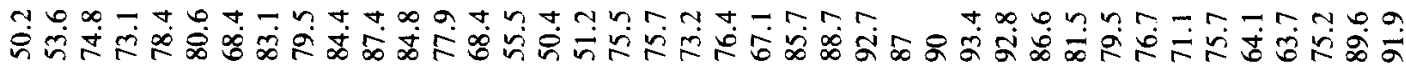

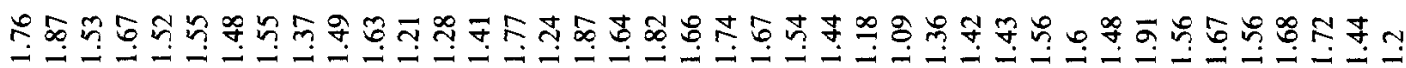

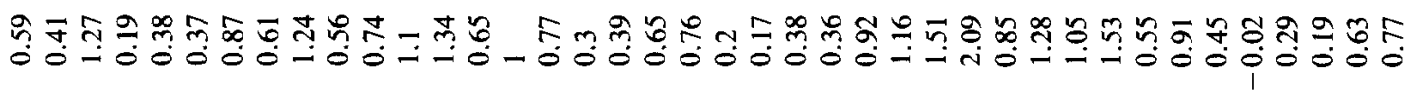

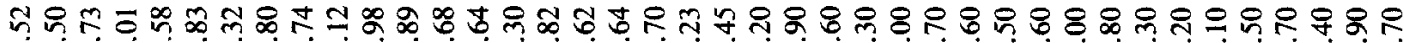

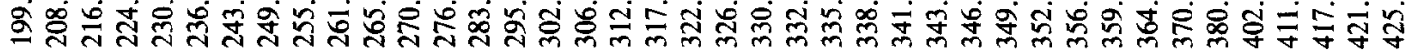

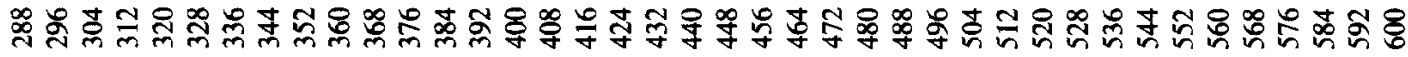




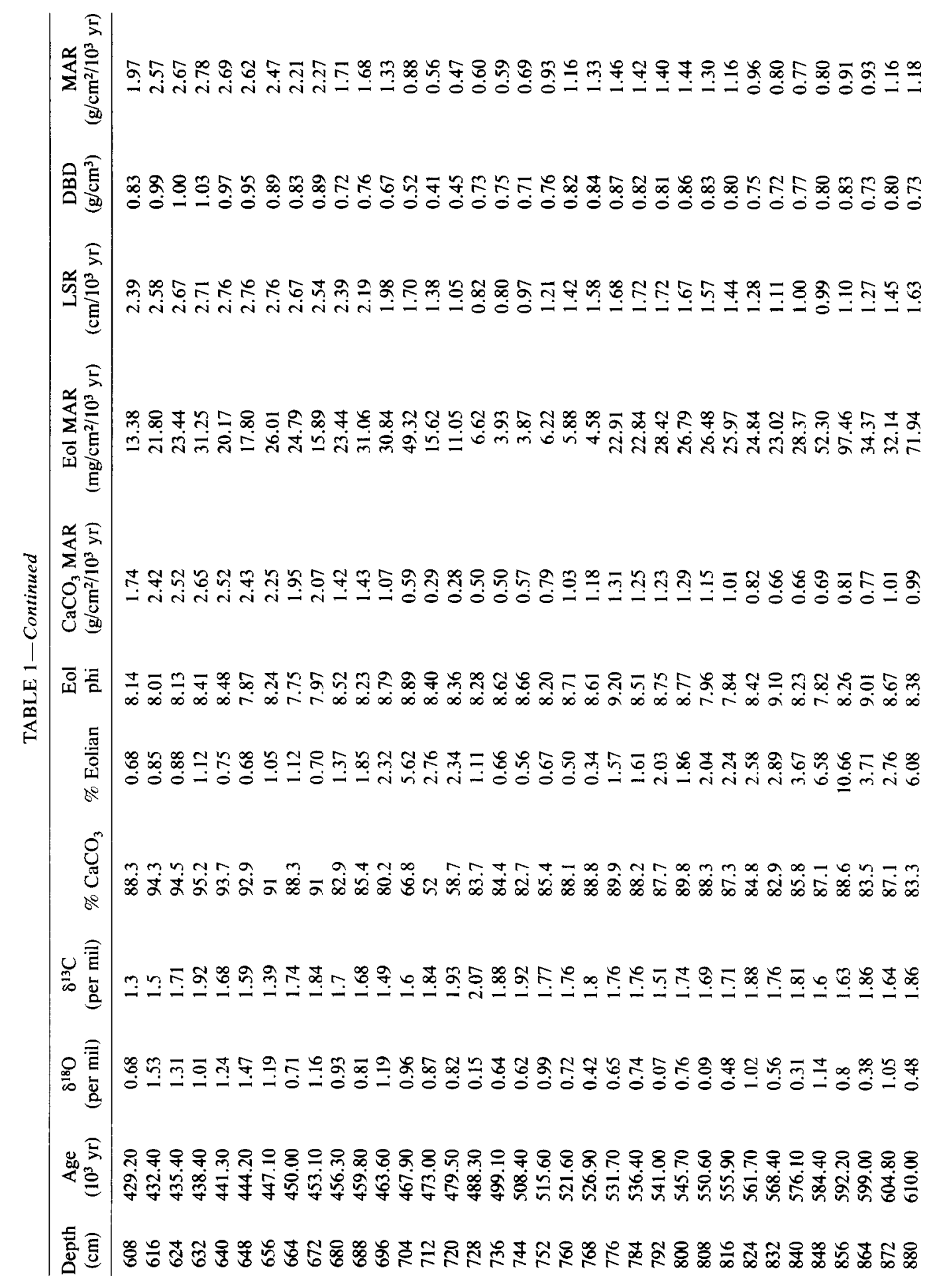




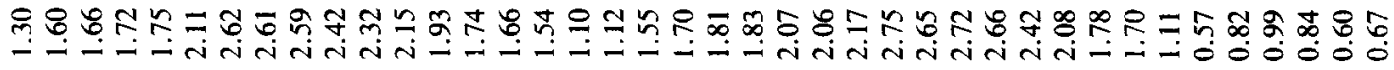

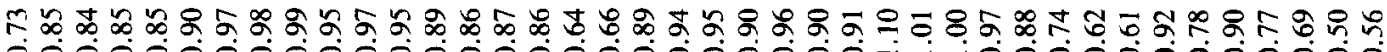

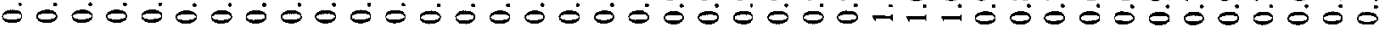

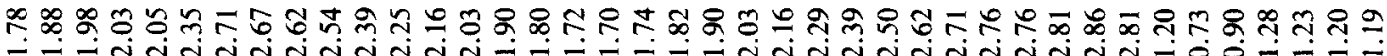

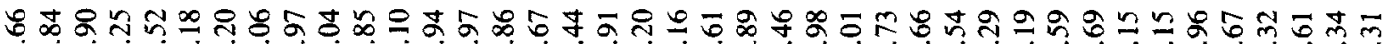

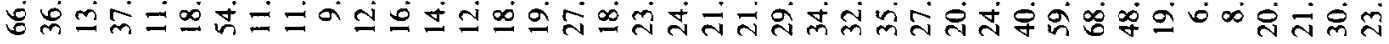

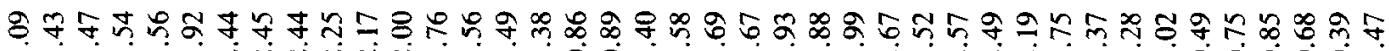

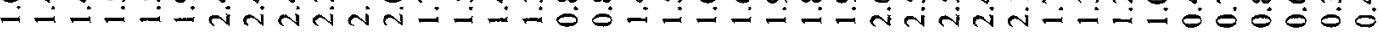

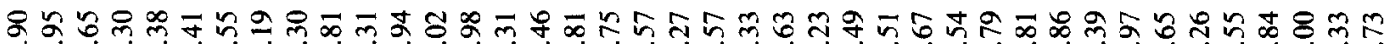

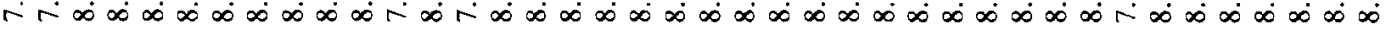

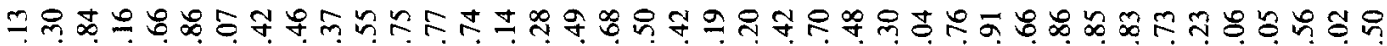

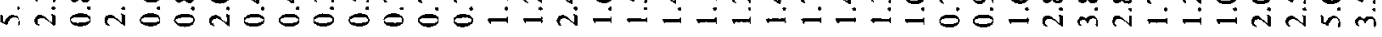

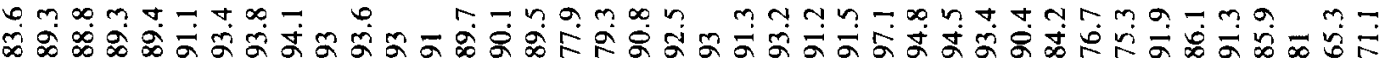

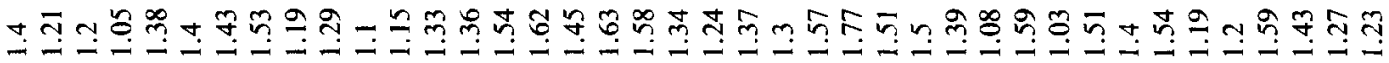

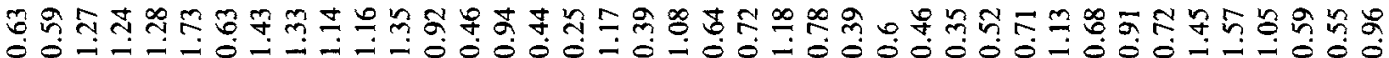

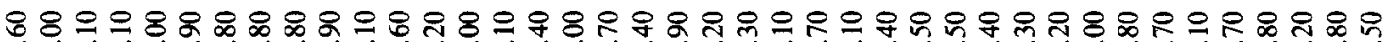

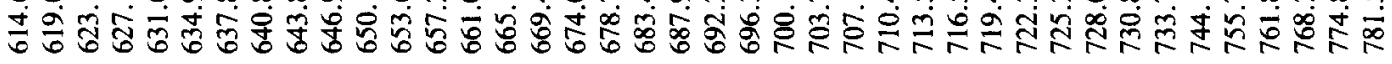

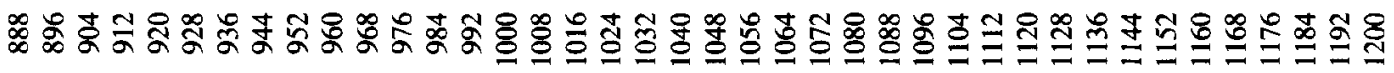




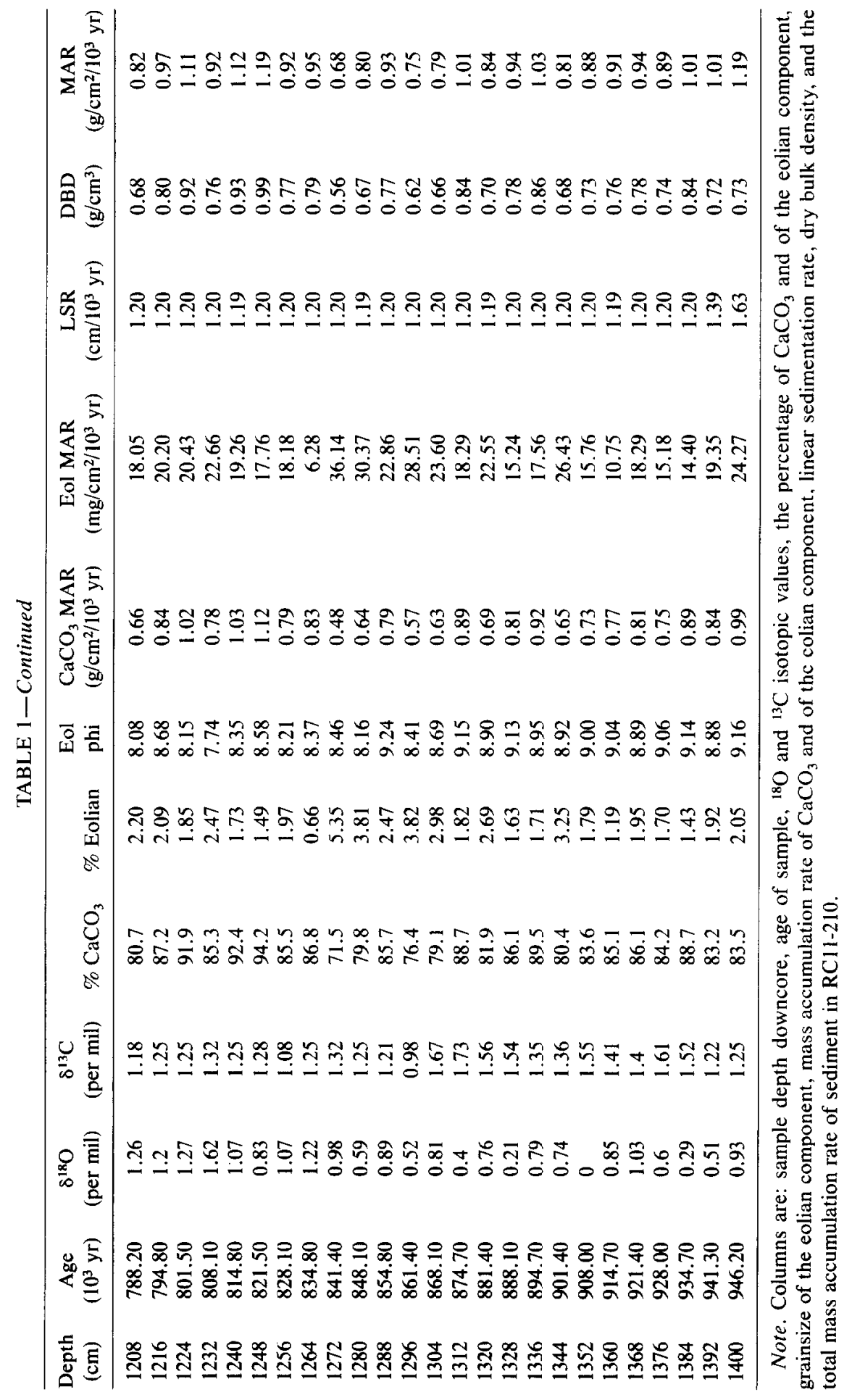


sets, the chronostratigraphy based upon the $\delta^{18} \mathrm{O}$ record, the calculations of the mass accumulation rates of calcium carbonate and eolian dust, and the eolian grainsize determinations, and we then discuss the paleoclimatic implications of these data. More complete time series analysis of the atmospheric and oceanic records from RC11-210 are given by Pisias and Rea (1987).

\section{THE MARINE CLIMATE RECORD}

The oxygen isotopic analyses provide a relatively clear $950,000-\mathrm{yr} \delta^{18} \mathrm{O}$ record (Fig. 2 ). The data range in value from -0.23 to +2.09 per mil, relative to PDB, and the record is generally similar to the SPECMAP $\delta^{18} \mathrm{O}$ record of Imbrie et al. (1984), as shown in Figure 3. Noticeable differences include a more highly depleted and double-peaked stage 5 and a more enriched stage 10. Several of the stages are difficult to distinguish, including stages 13 through 15 and 17 through 19 . The record prior to stage 22 displays smaller amplitude and higher frequency fluctuations, as do other $\delta^{18} \mathrm{O}$ records of this age (Shackleton and Opdyke, 1976; Pisias and Moore, 1981; Prell, 1982; Ruddiman et al., 1986).

The $\delta^{18} \mathrm{O}$ record was used to develop a time scale for RC11-210 by mathematically mapping it into the SPECMAP oxygen isotope record of Imbrie et al. (1984) by the inverse correlation technique of Martinson et al. (1982). This technique has previously been used successfully in the correlation of $\delta^{18} \mathrm{O}$ (Pisias et al., 1984) and $\mathrm{CaCO}_{3}$ records (Pisias et al., 1985) of different cores. The SPECMAP record only goes back to 782,000 yr (and loses some reliability below the Brunhes/Matuyama boundary at $730,000 \mathrm{yr}$ ), so the time scale for the oldest portion of our record was determined by correlation to the $\delta^{18} \mathrm{O}$ record of core V28-239. This procedure resulted in an age determination for each sample, allowing us to plot our data against time, rather than depth in core. Since an age/ depth relationship was obtained for each data point, this process also yielded an extremely detailed linear sedimentation rate record for all but the lowermost portion of the core (Fig. 3). Sedimentation rates rangc from 0.5 to $3.0 \mathrm{~cm} / 1000 \mathrm{yr}$ and consist of a series of broad highs and lows, with an average amplitude of about $1.5 \mathrm{~cm} / 1000 \mathrm{yr}$.

The $\delta^{13} \mathrm{C}$ data show the glacial/interglacial cycles much less clearly than the $\delta^{18} \mathrm{O}$ record, but there is a general correspondence of enriched $\delta^{13} \mathrm{C}$ values with depleted $\delta^{18} \mathrm{O}$ values (Fig. 2). The $\delta^{13} \mathrm{C}$ data range from +0.98 to +2.11 per mill relative to PDB, and there is an overall shift in the $\delta^{13} \mathrm{C}$ record at $620,000 \mathrm{yr}$, with the older material having an average $\delta^{13} \mathrm{C}$ value of 0.3 per mil lower than the younger material. Another apparent shift of average $\delta^{13} \mathrm{C}$ may occur at almost $870,000 \mathrm{yr}$, with mate-
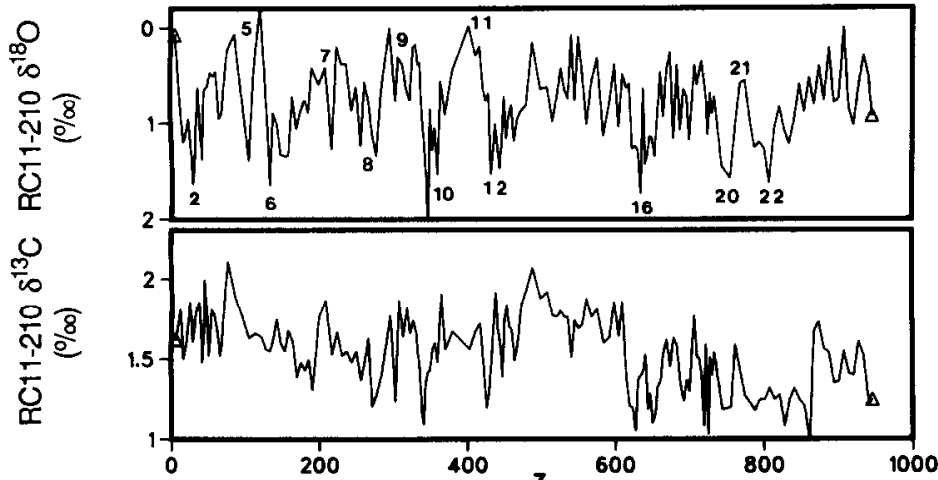


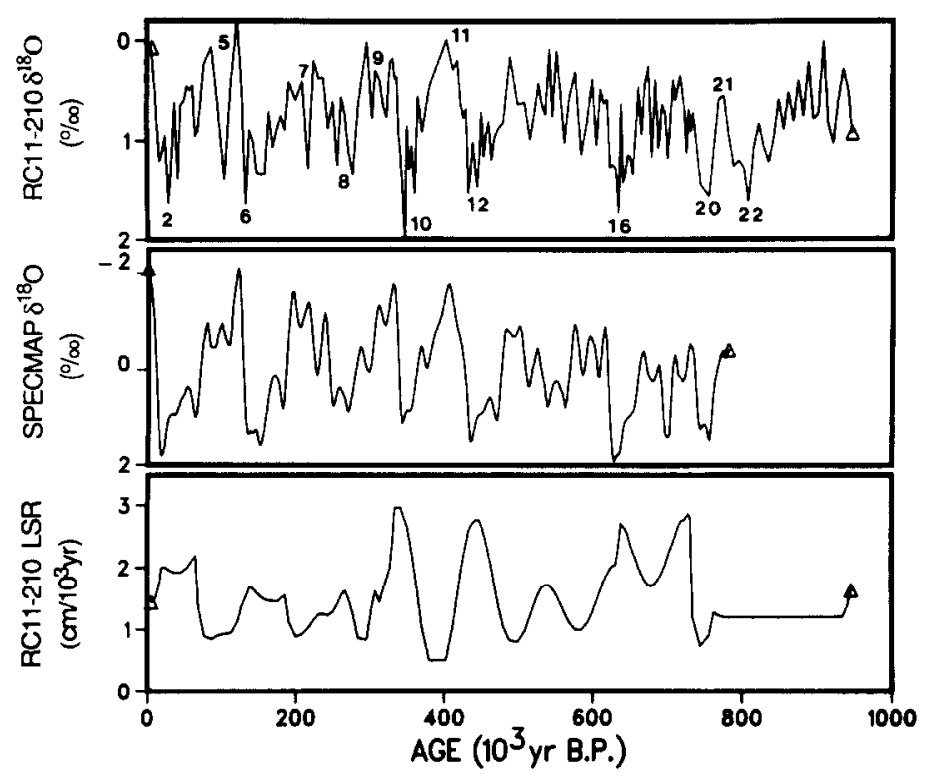

FIG. 3. Linear sedimentation rate (LSR), SPECMAP stacked and averaged $\delta^{18} \mathrm{O}$ profile and RC11-210 $\delta^{18} \mathrm{O}$ record.

rial older than this being 0.1 per mil enriched in ${ }^{13} \mathrm{C}$ relative to the younger material.

Mass accumulation rates in $\mathrm{g} / \mathrm{cm}^{2} / 1000 \mathrm{yr}$ were calculated as the product of linear sedimentation rates in $\mathrm{cm} / 1000 \mathrm{yr}$ and dry bulk density in $\mathrm{g} / \mathrm{cm}^{3}$. Ideally, dry bulk density data are based on porosity, which is determined by water loss from fresh samples. Samples used in this study were desiccated before arriving at our laboratory, so we generated dry bulk density data using an empirical relationship between dry bulk density and $\mathrm{CaCO}_{3}$ percentage determined for fresh samples from nearby core W8402A-14GC (Murray, 1987).

The percentage of calcium carbonate data from RC11-210 (Fig. 4) clearly records glacial carbonate events B2 through M2 (nomenclature of Hays et al., 1969) similar to but more detailed than the RC11-210 carbonate record published by Thompson and Saito (1974). Values range from 50 to $97 \% \mathrm{CaCO}_{3}$ (Fig. 4). Stages $\mathrm{B} 2$ and $\mathrm{B} 4$ are broad, multipeaked stages which are separated by $\mathrm{B} 3$, a long and highly variable stage of moderately severe carbonate dissolution. Stages B5 through B11 are a series of high-amplitude fluctuations, with an average stage-to-stage carbonate fluctuation of $37 \%$. The section of this record older than 488,000 yr (B11/B12) displays about half as much variation in $\mathrm{CaCO}_{3}$ content. Another change in the character of this record occurs at $848,000 \mathrm{yr}$, with the older portion of the record fluctuating at a higher frequency and lower amplitude, much like the $\delta^{18} \mathrm{O}$ record prior to isotope stage 22.

$\mathrm{CaCO}_{3}$ mass accumulation rate data were then calculated by multiplying the $\mathrm{CaCO}_{3}$ percentage values of each sample by its total mass accumulation rate. The flux of $\mathrm{CaCO}_{3}$ for $\mathrm{RC} 11-210$ ranges from 0.2 to $2.4 \mathrm{~g} / \mathrm{cm}^{2} / 1000 \mathrm{yr}$ and fluctuations in this record generally correspond with fluctuations in the $\mathrm{CaCO}_{3}$ percentage record (Fig. 4). Unlike the $\mathrm{CaCO}_{3}$ percentage record, the carbonate mass accumulation rates do not show a significant change of character at $488,000 \mathrm{yr}$. They do display a sudden decrease in amplitude at about $780,000 \mathrm{yr}$, a direct result of the change in the linear sedimentation rate record then.

The concentration of eolian dust in these sediments fluctuates by nearly two orders 


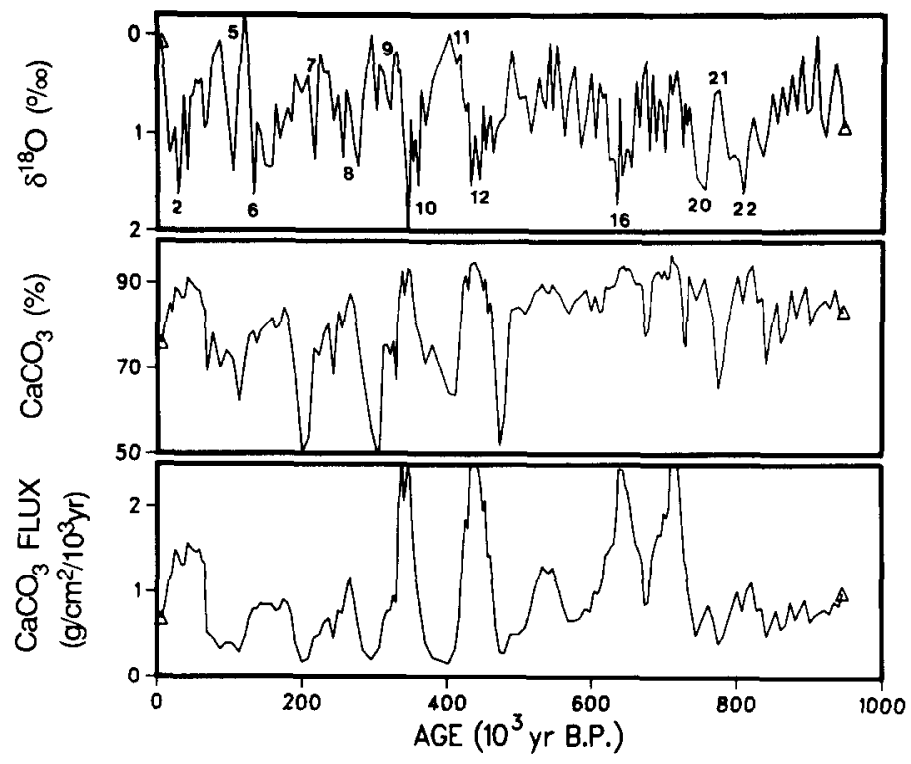

FIG. 4. Flux and percentage of $\mathrm{CaCO}_{3}$ and $\delta^{18} \mathrm{O}$ records from $\mathrm{RC} 11-210$.

of magnitude (Fig. 5). The conspicuously high peaks younger than $50,000 \mathrm{yr}$ are defined by eight samples, and since our samples are processed in batches of eight and these samples were the first to be extracted, these peaks are thought to be anomalous data. There is also a high peak at about $75,000 \mathrm{yr}$, which correlates to a greenish ash layer at this horizon. The rest of the eolian percentage record varies from 0.3 to $10.7 \%$. These fluctuations in eolian percentage result from variations in carbonate, because carbonate is the dominant component in these sediments, so any fluctuations in carbonate input will create large inverse fluctuations in the relative importance of the lesser components. To determine how eolian sedimentation rates changc, it is necessary to calculate the record of eolian mass accumulation rate (Fig. 5). Values of eolian mass accumulation rate range from 4 to $90 \mathrm{mg} / \mathrm{cm}^{2} / 1000 \mathrm{yr}$. In general, the flux of eolian material to site RC11-210 was higher during glacial times than during interglaciations. This is most evident in the lower part of the record for glacial stages 10 through 20 , which display an average glacial/interglacial variation of
$35 \mathrm{mg} / \mathrm{cm}^{2} / 1000$ yr. Like the $\mathrm{CaCO}_{3}$ mass accumulation rate record, the eolian mass accumulation rate record decreases in variability at $780,000 \mathrm{yr}$ due to the change in the linear sedimentation rate record then.

Eolian grainsize (Fig. 5) ranges from 9.30 $\phi(1.58 \mu \mathrm{m})$ to $7.18 \phi(6.90 \mu \mathrm{m})$, which is significantly more variation than that reported by an eolian grainsize study of a Pacific core from beneath the prevailing westerlies (Core KK7502; Janecek and Rea, 1985). Although the most conspicuous peaks in grainsize occur just prior to terminations of glacial events (specifically stages 8,10 , and 12), this record generally fluctuates at a higher frequency than the 100,000 -yr cycles displayed by the carbonate and oxygen isotope records (Pisias and Rea, 1987). A sudden shift in the character of the eolian grainsize record occurs at 277,000 to $326,000 \mathrm{yr}$. Samples younger than this display less size variability than do those older than this 300,000-yr-old event. There is another change in the character of this record at $875,000 \mathrm{yr}$, with the portion of the record older than this displaying about $0.5 \phi$ smaller grainsize and much less variation. 


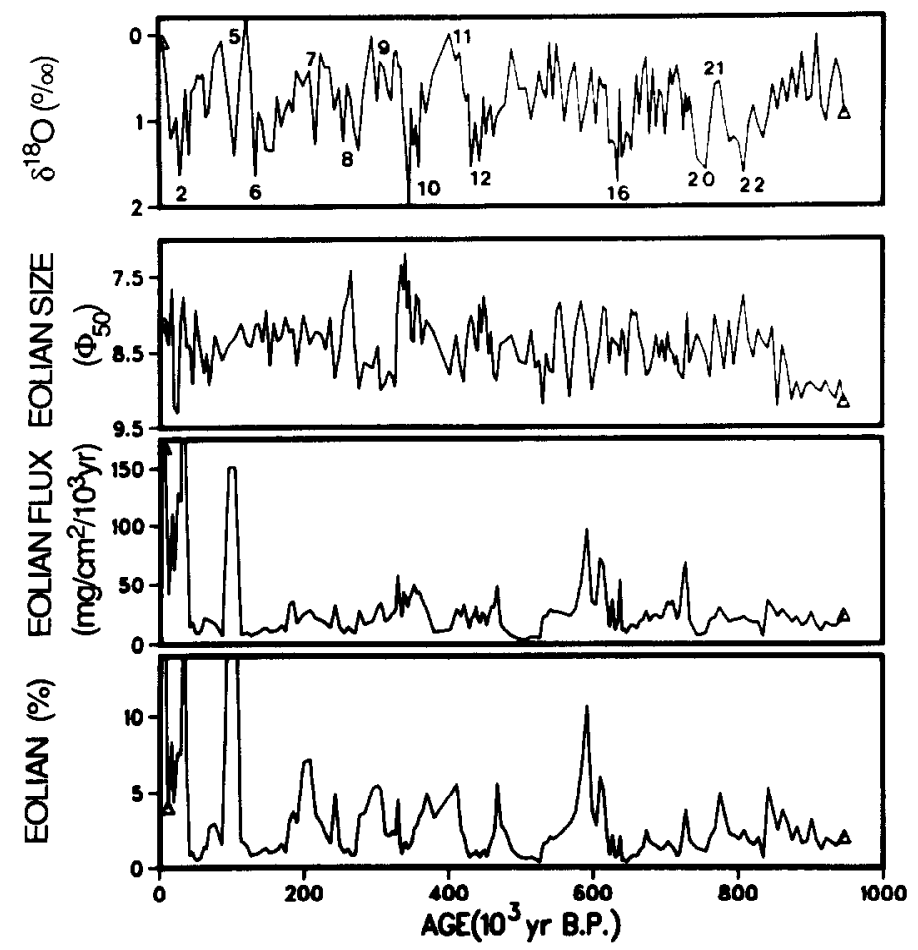

Fig. 5. Percentage, flux, and grainsize of the eolian component and the $\delta^{18} \mathrm{O}$ records from RC11-210.

\section{PALEOCLIMATIC IMPLICATIONS}

The $\delta^{18} \mathrm{O}$ data of $\mathrm{RC} 11-210$ represent a fairly clear record of global ice volume fluctuation. When this record is compared to the SPECMAP $\delta^{18} \mathrm{O}$ record (Fig. 3), several differences are apparent. A possible explanation for some of these discrepancies may be found in the detailed linear sedimentation rate record we generated for RC11-210. For example, unlike the SPECMAP record, stage 10 in $\mathrm{RC} 11-210$ is the most isotopically enriched stage in Brunhes time, while stage 14 is virtually nonexistent. Upon examination of the linear sedimentation rate record, it is seen that the highest value is reached during stage 10 , while stage 14 sedimentation rate values are the lowest for any glacial (evennumbered) stage in Brunhes time. Assuming constant rates of sediment mixing due to bioturbation, sediments deposited at low rates will be more homogenized, and will therefore show lower amplitude extremes of paleoclimatic indicators such as $\delta^{18} \mathrm{O}$ (Shackleton and Opdyke, 1976).

The linear sedimentation rate record was generated by a method which was independent of carbonate content, so the common assumption that high $\mathrm{CaCO}_{3}$ percentage corresponds with high sedimentation rates can be tested by comparing the sedimentation rate and $\mathrm{CaCO}_{3}$ percentage records. The two records correlate well. Furthermore, the sedimentation rate variations also correlate well with planktonic foraminiferal dissolution cycles for RC11-210 (Thompson and Saito, 1974) which show intense dissolution at horizons where linear sedimentation rates and carbonate amounts are low. Therefore, in pelagic carbonate oozes of the central equatorial Pacific, linear sedimentation rate varies with $\mathrm{CaCO}_{3}$ percentage. This effect has long been suspected, but not previously demonstrated from independent data. 
When the $\mathrm{CaCO}_{3}$ percentage record and $\delta^{18} \mathrm{O}$ record are compared, the correlation between high ice volume and good carbonate preservation is apparent (Fig. 4). No consistent pattern of temporal leads or lags occur when these two records of glacial fluctuation are compared.

Core RC11-210 is located beneath the southeast tradewinds, so the source region for the eolian material deposited here might be expected to be northern South America. The accumulation of eolian material is interpreted to indicate aridity of the eolian source region, and the RC11-210 eolian mass accumulation rate record shows no apparent correlation to glacial stages in sediments younger than $330,000 \mathrm{yr}$. In older materials, dust accumulation is enhanced during glacial times. In comparison, pollen studies in the northern Andes (Hooghiemstra, 1984; van der Hammen, 1985 ) and a study of eolian sedimentation at Deep Sea Drilling Project core 503B, approximately $4900 \mathrm{~km}$ east of $\mathrm{RC} 11-210$ in the equatorial Pacific (Fig. 1; Rea et al., 1986) indicate relatively humid glacial intervals in the Andes. The 503B study shows a correlation between eolian flux peaks and interglacial times, and the eolian mass accumulation rate values generated for that core range from 24 to $169 \mathrm{mg} / \mathrm{cm}^{2} /$ $1000 \mathrm{yr}$, higher than the eolian mass accumulation rate in RC11-210.

RC11-210 may be receiving eolian material from a source other than South America. Arid regions of China are now supplying eolian material to the Marshall Islands (Duce et al., 1980), and quartz $\delta^{18} \mathrm{O}$ studies suggest that Hawaiian Island dust has a similar source (Clayton et al., 1972). These island chains are within the northeasterly tradewinds, yet they receive eolian material from a source region to the northwest. Duce et al. (1980) show that this eolian material is carried southeastward by the strong westerlies which exist about $3000 \mathrm{~m}$ above the northwest Pacific. These winds bring Asian dust into the tradewinds, which then carry it westward. If similar wind patterns exist in the southern hemisphere, then Australia is a possible source region for the eolian material found at RC11-210, and this record indicates a glacial increase in the aridity of Australia, at least between 300,000 and 800,000 yr ago. Alternatively, dust from China may cross the intertropical convergence zone.

The eolian grainsize record suggests some correlation between glacial stages and increased wind intensities. Such a relationship would agree with predicted increased glacial thermal gradients (CLIMAP, 1976, 1981) and with other marine sediment studies both in the Atlantic (Parkin and Shackleton, 1973) and in the Pacific (Janecek and Rea, 1985). The dominant character of the eolian grainsize record, however, is one that fluctuates at a higher frequency than the 100,000 -yr glacial/interglacial cycles (Pisias and Rea, 1987).

By applying a mathematical relationship between particle radius and wind velocity, the eolian grainsize data shown in Figure 4 can be used to determine relative changes in the wind intensity. Janecek and Rea (1985) supply an appropriate equation,

$$
R_{\mathrm{w}}=D \mathrm{~h}^{2} / D \mathrm{l}^{2},
$$

where

$$
\begin{aligned}
D \mathrm{~h}= & \text { the larger of two grain diameters } \\
& \text { to be compared (in micrometers), } \\
& \text { representing higher wind inten- } \\
& \text { sity; } \\
D \mathrm{l}= & \text { the smaller of two grain diameters } \\
& \text { to be compared, representing } \\
& \text { lower wind intensity; and } \\
R_{\mathrm{w}}= & \text { the ratio of higher to lower wind } \\
& \text { intensities. }
\end{aligned}
$$

Using this equation, the peaks and troughs of the grainsize record are compared to determine the amount of wind intensity fluctuation. The average ratio of high- to low-wind intensity prior to the event at $300,000 \mathrm{yr}$ is 6.25 , whereas the 
average ratio indicated by the younger sediments is 2.61. This suggests a marked decrease in wind intensity fluctuations beginning about $300,000 \mathrm{yr}$ ago, a change that has also been observed previously in two Pacific cores, KK 7502 from the northern hemisphere westerlies and DSDP 503B in the northern hemisphere tradewinds (Janecek and Rea, 1985).

Recently, Jansen et al. (1986) compiled much of the data suggesting a change in climatic regime during the mid-Brunhes, an event previously reported from the north Pacific by several authors (Pisias, 1976; Sancetta and Silvestri, 1984; Pisias and Leinen, 1984; Janecek and Rea, 1985; Schramm, 1985). Events assumed to be coeval by Jansen et al. (1986) do not all occur at the same time. In core RC11-210 the change in Pacific $\mathrm{CaCO}_{3}$ preservation cited by Jansen et al. occurs about 488,000 yr ago and the change in eolian size parameters, also cited, occurs about $300,000 \mathrm{yr}$ ago. The younger event is probably correlative with the change in oceanic proxy circulation indicators based on siliceous plankton, as reported by Sancetta and Silvestri (1984), Pisias and Leinen (1984), and Schramm (1985), and we believe, marks the true mid-Brunhes event in the Pacific. This observation of the mid-Brunhes event in records of atmospheric and sea-surface circulation, but not in deep water $\left(\mathrm{CaCO}_{3}\right)$ records, implies that the thermocline may be a boundary between the climate subsystems equal in importance to the air-sea interface.

The eolian grainsize record also indicates that prior to $875,000 \mathrm{yr}$, both the intensity and variability of atmospheric circulation were much lower. These changes in the eolian record precede changes in the records of $\mathrm{CaCO}_{3}$ percentage at $855,000 \mathrm{yr}$ and $\delta^{18} \mathrm{O}$ at $848,000 \mathrm{yr}$, which indicate a rather sudden inception of large amplitude climatic fluctuations during this $27,000-y r$ time span. This boundary between "early Pleistocene" and "late Pleistocene" has been well established in $\mathrm{CaCO}_{3}$ and $\delta^{18} \mathrm{O}$ records (Shackleton and Opdyke, 1976; Pisias and Moore, 1981; Prell, 1982; Ruddiman et al., 1986), but RC11-210 supplies the first paleowind-related evidence of this event and shows that at this location the transition to larger amplitude fluctuations in atmospheric phenomena leads oceanic $\left(\mathrm{CaCO}_{3}\right)$ and ice volume $\left(\delta^{18} \mathrm{O}\right)$ changes by 20,000 to $27,000 \mathrm{yr}$ ( 3 or 4 sample intervals).

\section{SUMMARY}

Core RC11-210 from the equatorial Pacific provides continuous $950,000-y r$ records of global ice volume, oceanic carbon isotopic content, bottom-water chemistry, continental aridity, and wind intensity. The $\mathrm{RC} 11-210 \delta^{18} \mathrm{O}$ record was compared to the SPECMAP $\delta^{18} \mathrm{O}$ record of Imbrie et al. (1984), yielding a detailed linear sedimentation rate record for the past $780,000 \mathrm{yr}$. The fluctuations in this linear sedimentation rate record coincide with fluctuations in independently generated $\mathrm{CaCO}^{3}$ percentage and foraminifera dissolution index records, demonstrating that sedimentation rate varies directly with $\mathrm{CaCO}_{3}$ percentage in these pelagic sediments.

The $\delta^{18} \mathrm{O}$ and $\mathrm{CaCO}_{3}$ percentage records are related in the normal Pacific pattern of enhanced carbonate preservation during glacial times. Little lag between $\delta^{18} \mathrm{O}$ and $\mathrm{CaCO}_{3}$ abundance patterns was observed. The $\mathrm{CaCO}_{3}$ percentage record shows a change of character at $488,000 \mathrm{yr}$, with interglacial stages prior to that time displaying much less dramatic dissolution than the younger interglaciations. In contrast, the $\mathrm{CaCO}_{3}$ mass accumulation rate record does not display a significant change then.

The amount of eolian material available for deposition in the oceans far from land masses is thought to be controlled by the aridity of the region supplying this dust. The eolian flux record shows increased eo- 
lian input during glacial times from 800,000 to $300,000 \mathrm{yr}$ ago, but the relationship is less obvious in younger sediments. Since RC11-210 lies within the southeasterly tradewinds, the expected source region would be northwestern South America. This record would therefore imply generally increased South American aridity during glacial times, in conflict with other, more direct evidence suggesting humid glacial conditions there. However, the presence of Gobi desert dust in the Marshall and Hawaiian Islands suggests that if northern and southern hemisphere wind patterns are similar, the eolian source region could be Australia. This record would then imply increased glacial aridity there.

The grainsize record of this material is interpreted as an indication of the intensity of atmospheric circulation. There is a general correlation between glacial maxima and increased wind velocities, but atmospheric circulation intensity commonly fluctuates at a higher frequency than the glacial cycles. A brief atmospheric "quiet time" occurs from 326,000 to $277,000 \mathrm{yr}$, during which there was decreased wind intensity and decreased variation in wind intensity. This event separates younger materials displaying reduced variability of eolian grainsize from older sediments with enhanced size variability and represents the atmospheric expression of the midBrunhes climatic event.

As in other cores, the $\mathrm{CaCO}_{3}$ and $\delta^{18} \mathrm{O}$ records show a lack of large-scale fluctuations prior to about $850,000 \mathrm{yr}$. This sudden change in climate variability is also shown in the eolian grainsize record of RC11-210, which shows a dramatic increase in variation and intensity of atmospheric circulation appearing at $875,000 \mathrm{yr}$, approximately $25,000 \mathrm{yr}$ earlier than the oxygen isotope and calcium carbonate proxy indicators.

\section{ACKNOWLEDGMENTS}

We thank Alan Mix and G. Ross Heath for thoughtful reviews. Samples were provided by the
Core Laboratory of Lamont-Doherty Geological Observatory. This work was supported by the NSF Climate Dynamics Program, Grant ATM-8308377.

\section{REFERENCES}

Adelseck, C. G., Ir., and Anderson, T. F. (1978). The late Pleistocene record of productivity fluctuations in the late eastern equatorial Pacific Ocean. Geology 6, 388-391.

Arrhenius, G. (1952). Sediment cores from the east Pacific: Properties of the sediments. Reports of the Swedish Deep-Sea Expedition 1947-1948 I, 1-228.

Arthur, M. A., Dean, W. E., and Schlanger, S. O. (1985). Variations in the global carbon cycle during the Cretaceous related to climate, volcanism, and changes in atmospheric $\mathrm{CO}_{2}$. In "The Carbon Cycle and Atmospheric $\mathrm{CO}_{2}$ : Natural Variations Archean to Present" (E. T. Sundquist and W. S. Broecker, Eds.), pp. 504-529. American Geophysical Union Monograph 32, Washington, DC.

Berger, W. G., Vincent, E., and Thierstein, H. G. (1981). The deep-sea record: Major steps in Cenozoic ocean evolution. In "The Deep Sea Drilling Project, A Decade of Progress" (J. E. Warme, R. G. Douglas, and E. L. Winterer, Eds.), pp. 489-504. Society of Economomic Paleontologists and Mineralogists Special Publication 32, Tulsa, OK.

Broecker, W. S., and Peng, T. H. (1982). "Tracers in the Sea.' Lamont-Doherty Geological Observatory, Palisades, New York.

Clayton, R., Rex, R., Syers, J., and Jackson, M. (1972). Oxygen isotope abundance in quartz from Pacific pelagic sediments. Journal of Geophysical Research 77, 3907-3915.

CLIMAP (1976). The surface of the ice-age Earth. Science 191, 1131-1137.

CLIMAP (1981). "Seasonal Reconstructions of the Earth"s Surface at the Last Glacial Maxima." Geological Society of America Map and Chart Series, MC-36. Boulder, CO.

Duce, R., Unni, C., Ray, B., Prospero, J., and Merrill, J. (1980). Long range atmospheric transport of soil dust from Asia to the tropical North Pacific: Temporal variability. Science 209, 1522-1524.

Emiliani, C. (1955). Pleistocene temperatures. Journal of Geology 63, 538-578.

Folk, R. L. (1974). "Petrology of Sedimentary Rocks." Hemphill, Austin, TX.

Hays, J. D., Saito, T., Opdyke, N. D., and Burckle, L. H. (1969). Pliocene-Pleistocene sediments of the equatorial Pacific: Their paleomagnetic, biostratigraphic, and climatic record. Geological Society of America Bulletin 80, 1481-1514.

Hooghiemstra, H. (1984). "Vegetational and Climatic History of the High Plain of Bognta, Columbia: A 
Continuous Record of the Last 3.5 Million Years." Cramer, Vaduz, Liechenstein.

Imbrie, J., Hays, J. D., Martinson, D. G., McIntyre, A., Mix, A. C., Morley, J. J., Pisias, N. G., Prell, W. L., and Shackleton, N. J. (1984). The orbital theory of Pleistocene climate: Support from a revised chronology of the marine $\delta^{18} \mathrm{O}$ record. In "Milankovitch and Climate" (A. Berger, J. Imbrie, J. Hays, G. Kukla, and B. Saltzman, Eds.), Part 1, pp. 269-305. Reidel, Dordrecht.

Janecek, T. R., and Rea, D. K. (1985). Quaternary fluctuations in northern hemisphere trade winds and westerlies. Quaternary Research 24, 150-163.

Jansen, J. H., Kuijpers, A., and Troelstra, S. R. (1986). A mid-Brunhes climatic event: Long-term changes in global atmosphere and ocean circulation. Science 232, 619-622.

Leinen, M., and Heath, G. R. (1981). Sedimentary indicators of atmospheric circulation in the northern hemisphere during the Cenozoic. Palaeogeography, Palaeoclimatology, Palaeoecology 36, 1-21.

Martinson, D., Menke, W., and Stoffa, P. (1982). An inverse approach to signal correlation. Journal of Geophysical Research 87, 4807-4818.

Murray, D. (1987) "Spatial and Temporal Variations in Sediment Accumulation in the Central Tropical Pacific." Unpublished Ph.D. dissertation, Oregon State University, Corvallis.

Parkin, D. W., and Padgham, R. C. (1975). Further studies on trade winds during the glacial cycles. Proceedings of the Royal Society of London, Series A 346, 245-260.

Parkin, D. W., and Shackleton, N. J. (1973). Trade wind and temperature correlations down a deep-sea core off the Saharan Coast. Nature (London) 245, $455-457$.

Pisias, N. G. (1976). Late Quaternary sediment of the Panama Basin: Sedimentation rates, periodicities, and controls of carbonate and opal accumulation. In "Investigation of Late Quaternary Paleoceanography and Paleoclimatology" (R. M. Cline and J. D. Hays, Eds.), pp. 375-391. Geological Society of America Memoir 145, Boulder, CO.

Pisias, N. G., Barron, J. A., Nigrini, C., and Dunn, D. A. (1985). Stratigraphic resolution of Leg 85 drill sites: An initial analysis. In "Initial Reports of the Deep Sea Drilling Project"' (L. Mayer, F. Theyer $e t$ al.), Vol. 85, pp. 695-708. U.S. Government Printing Office, Washington, DC.

Pisias, N. G., and Leinen, M. (1984). Milankovitch forcing of the oceanic system: Evidence from the northwest Pacific. In "Milankovitch and Climate" (A. Berger, J. Imbrie, J. Hays, G. Kukla, and B. Saltzman, Eds.), Part 1, pp. 307-330. Riedel, Dordrecht.

Pisias, N. G., Martinson, D., Moore, T. C., Jr., Shackleton, N. J., Prell, W. L., Hays, J., and
Boden, G. (1984). High resolution stratigraphic correlation of benthic oxygen isotope records spanning the last 300,000 years. Marine Geology 56, 119-136.

Pisias, N. G., and Moore, T. C., Jr. (1981). The evolution of Pleistocene climate: A time series approach. Earth and Planetary Science Letters 52, 450-458.

Pisias, N. G., and Rea, D. K. (1987). Late Pleistocene paleoclimatology of the central Equatorial Pacific: Sea-surface response to the southeast tradewinds. Paleoceanography, in press.

Prell, W. L. (1982). Oxygen and carbon isotope stratigraphy for the Quaternary of Hole 502B: Evidence for two modes of isotope variability. In "Initial Reports of the Deep Sea Drilling Project," (W. L. Prell, J. V. Gardner et al.), Vol. 68, pp. 455-464. U.S. Government Printing Office, Washington, DC.

Prospero, J. M., Glaccum, R. A., and Nees, R. T. (1981). Atmospheric transport of soil dust from Africa to South America. Nature (London) 289, 570-572.

Prospero, I. M., and Nees, R. T. (1977). Dust concentrations in the atmosphere of the equatorial North Atlantic: Possible relationships to the Sahalian droughts. Science 196, 1196-1198.

Rea, D. K., Chambers, L. W., Chuey, J. M., Janecek, T. R., Leinen, M., and Pisias, N. G. (1986). A 420,000 -year record of cyclicity in oceanic and atmospheric processes from the eastern Equatorial Pacific. Paleoceanography 1, 577-586.

Rea, D. K, , and Janecek, T. R. (1981). Mass accumulation rates of non-authigenic inorganic crystalline (eolian) component of deep sea sediments from the western Mid-Pacific Mountains, Deep Sea Drilling Project Site 463. In "Initial Reports of the Deep Sea Drilling Project" (J. Thiede, T. L. Vallier, et al.), Vol. 62, pp. 653-659. U.S. Government Printing Office, Washington, DC.

Rea, D. K., Leinen, M., and Janecek, T. R. (1985). A geologic approach to the long-term history of atmospheric circulation. Science 227, 721-725.

Ruddiman, W. F., Raymo, M., and McIntyre, A. (1986). Matuyama 41,000-year cycles: North Atlantic Ocean and northern hemisphere ice sheets. Earth and Planetary Science Letters 80, 117-129.

Sancetta, C., and Silvestri, S. (1984). Diatom stratigraphy of the late Pleistocene (Brunhes) subarctic Pacific. Marine Micropaleontology 9, 263-274.

Schramm, C. T. (1985). Implications of radiolarian assemblages for the late Quaternary paleoceanography of the eastern Equatorial Pacific. Quaternary Research 24, 204-218.

Shackleton, N. J. (1967). Oxygen isotope analyses and Pleistocene temperatures re-assessed. Nature (London) 218, 15-17.

Shackleton, N. J. (1977a). The oxygen isotope stratigraphic record of the late Pleistocene. Philosophical 
Transactions of the Royal Society of London, Series B 280, 169-182.

Shackleton, N. J. (1977b). Tropical rainforest history and the equatorial Pacific carbonate dissolution cycles. In "The Fate of Fossil Fuel $\mathrm{CO}_{2}$ in the Oceans" (N. R. Andersen and A. Malahoff, Eds.), pp. 401-428. Plenum, New York.

Shackleton, N. J., and Opdyke, N. D. (1976). Oxygen isotope and paleomagnetic stratigraphy of V28-239, late Pliocene to latest Pleistoce. In "Investigation of Late Quaternary Paleoceanography and Paleoclimatology" (R. M. Cline and J. D. Hays, Eds.), pp. 449-464. Geological Society of America Memoir 145. Boulder, $\mathrm{CO}$.

Shackleton, N. J., and Pisias, N.G. (1985). Atmo- spheric carbon dioxide, orbital forcing, and climate. In "The Carbon Cycle and Atmospheric $\mathrm{CO}_{2}$ : Natural Variations Archean to Present" (E. T. Sundquist and W. S. Broecker, Eds.), pp. 303-317. American Geophysical Union Monograph 32, Washington, DC.

Thompson, P. R., and Saito, T. (1974). Pacific Pleistocene sediments: Planktonic foraminifera dissolution cycles and geochronology. Geology 2, 333-335.

van der Hammen, 'T. (1985). The Plio-Pleistocene climatic record of the tropical Andes. Journal of the Geological Society of London 142, 483-489.

Windom, H. L. (1975). Eolian contributions to marine sediments. Journal of Sedimentary Petrology 45, $520-529$. 